\title{
Effect of functional solutions applied in machinery on fuel consumption and emissions
}

\author{
Jerzy Napiórkowski ${ }^{1,}{ }^{,}$, Jarosław Gonera ${ }^{1}$, Piotr Szczyglak ${ }^{1}$, and Robert Czarnecki ${ }^{1}$ \\ ${ }^{1}$ Department of Design and Operation of Vehicles and Machines, University of Warmia and Mazury \\ in Olsztyn
}

\begin{abstract}
Because stricter norms of emission of hazardous substances are being introduced every few years, machinery manufacturers are also forced to introduce various modifications to reduce emissions. To this end, systems aimed at optimising the process of fuel combustion and reducing the amount of hazardous compounds are being applied. Three tractors used in agriculture, with various functional solutions, were examined in this study. The effect of various systems on reduction of hazardous emissions and fuel consumption was determined. The tests were conducted during the ploughing with a 4-bottom swivel plough. The effect of the selective reduction (SCR) system with AdBlue liquid, the exhaust gas recirculation (EGR) system, the particulate filter, the number of valves per cylinder and the type of a turbocharger in the engine's inlet system were determined. It was observed during the tests that there were differences in fuel consumption and emissions depending on the constructional solutions applied in the tractors.
\end{abstract}

\section{Introduction}

As increasingly strict norms are introduced regarding exhaust emissions from combustion engines, it is necessary to apply various systems reducing hazardous emissions. Successive TIER/EURO Stage norms (Fig. 1) which apply to machinery, have put a particular emphasis on the reduction of emission of $\mathrm{NO}_{x}$, i.e. nitrogen oxides, and reducing the emission of particulate matter (PM) [4]. Emission of hydrocarbons is also reduced in successive norms (HC). In order to reduce emissions, manufacturers of vehicles apply modern systems to reduce hazardous emissions, both inside and outside of engines.

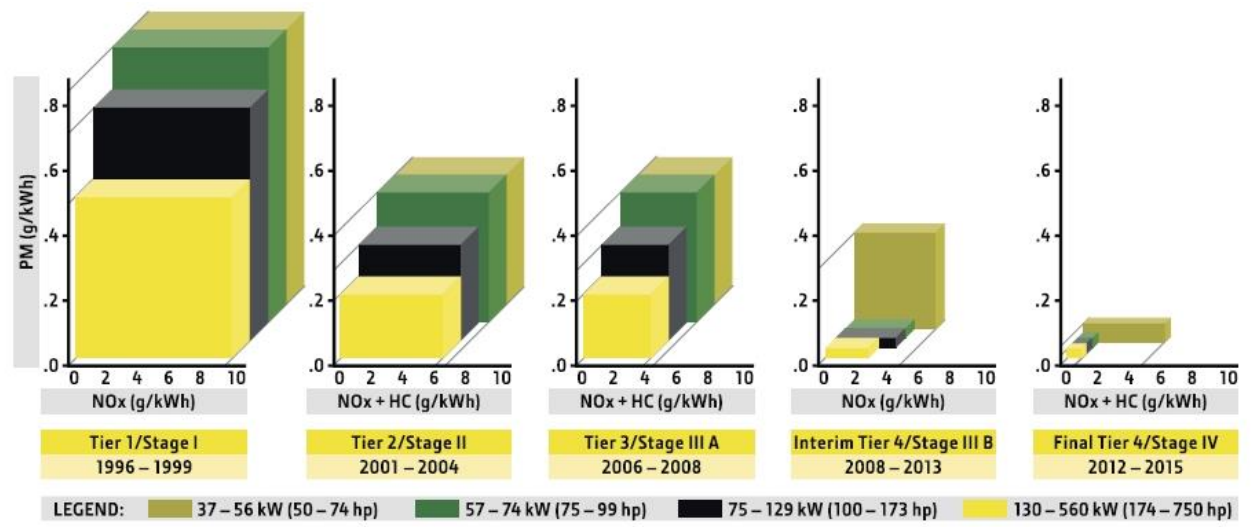

Fig. 1. Valid norms of emissions for agricultural tractors with the power ranging from $37 \mathrm{~kW}$ to 560 $\mathrm{kW}$. [13]

\footnotetext{
*Corresponding author: jerzy.napiorkowski@uwm.edu.pl
} 
The method of emission reduction in an engine consists in optimisation of fuel combustion, in particular in the environmental aspect. Such reduction also means lower fuel consumption, which also brings an economic benefit [1]. Norms of fuel emissions depend on the power of the engine installed in a tractor. Such tests are conducted according to the Stage norms in Europe and the Tiere norm in North America [5].

For example, a comparison of the Tiere 2/Stage II norm with the Final Tiere 4/Stage IV norm shows that the sum of $\mathrm{NO}_{\mathrm{x}}$ and $\mathrm{HC}$ was reduced several dozen times in each of the four engine categories. Reduction of particulate matter was achieved mainly by applying non-engine methods, such as particulate filters. For $\mathrm{NO}_{\mathrm{x}}$ emission, the main focus was on its reduction by engine-related methods, i.e. by optimising the combustion process. To this end, Common Rail systems were applied, in which a fuel dose is divided into several portions, as well as modern constructions of EGR systems together with advanced algorithms of controlling operation of combustion engines [5]. Exhaust emissions from agricultural tractors are usually reduced by the use of EGR systems, catalysts (catalytic converters), which are used for after-burning of hydrocarbons and carbon oxides, diesel particulate filters (DPF) and systems of selective catalytic reduction of $\mathrm{NO}_{\mathrm{x}}$ using AdBlue reducing liquid (high purity, $32.5 \%$ aqueous solution of urea) $[5,9]$.

A high content of $\mathrm{NO}_{\mathrm{x}}$ in exhaust gas has an adverse effect on human health because when absorbed by the body - it reacts with haemoglobin and can cause weakness, numbness of limbs, pulmonary oedema and heart damage. Large amounts of CO also bind to haemoglobin, resulting in hypoxia and consequent brain damage and mental changes. Hydrocarbons have carcinogenic properties, they accumulate in the body and are lethal in high concentrations $[1,5,10]$.

\section{Functional solutions in agricultural tractors}

Considerable changes have been made in the construction of machinery, particularly in agricultural tractors, since 2004. The machine fleet has been modernised owing to the bridge programme. Despite this, there are several machines with obsolete functional solutions operating in the Polish economy [7].

Large amounts of hazardous substances are particularly emitted by older machines, with traditional systems of fuel supply, based on injection pumps. In such machines, exhaust gas emission is exceeded many times compared to modern tractors. A reduction in the number of operated tractors of this kind can bring a considerable improvement in air quality [10]. For example, up to 55\% of tractors registered in 2012-2016 were older than 20 years.

Complex processes take place during the operation of machinery (including agricultural tractors) in difficult and variable environmental and atmospheric conditions. These machines are operated both on public roads and - usually - under difficult field conditions. Depending on the conditions, various wear and destructive processes take place. Wear and destruction frequently results in an increase in emissions and fuel consumption by tractors [3].

Considering the fact that certification tests are conducted under laboratory conditions, their outcome may differ from the results obtained in real-life conditions, during normal operation of machinery. This is of particular importance for tractors which are operated under specific field conditions [8].

Proper setting up of the machine aggregate, for example, for ploughing, is one of aspects which may bring about a reduction of emissions and fuel consumption [5]. It is the most energy-consuming operation in agriculture, with a tractor working at variable engine rotational speed, load and torque demand [10].

A high level of purity of exhaust gases in agricultural tractors is also important because some of them may also work indoors: in poultry houses, pigsties, cowsheds. In such cases, exhaust gases have an effect both on the health of the operators and of farm animals. $\mathrm{NO}_{\mathrm{x}}$ 
and $\mathrm{HC}$ have a particularly adverse effect on animals because it results in a lower quality of milk and meat [6]. Therefore, only tests conducted in real-life conditions provide results illustrating the actual harmfulness of combustion engines.

An SCR exhaust gas treatment system (Fig. 2) decomposes harmful nitrogen oxides $\left(\mathrm{NO}_{\mathrm{x}}\right)$ to water and nitrogen. AdBlue liquid - an aqueous solution of urea - is used in the treatment process [7]. AdBlue liquid is injected to the system by an injector. SCR systems are relatively failure-prone because AdBlue crystallises at approx. $-11 \mathrm{oC}$, clogging the injector and tubing, and subsequently damaging the liquid pump and the $\mathrm{NO}_{\mathrm{x}}$ sensor.

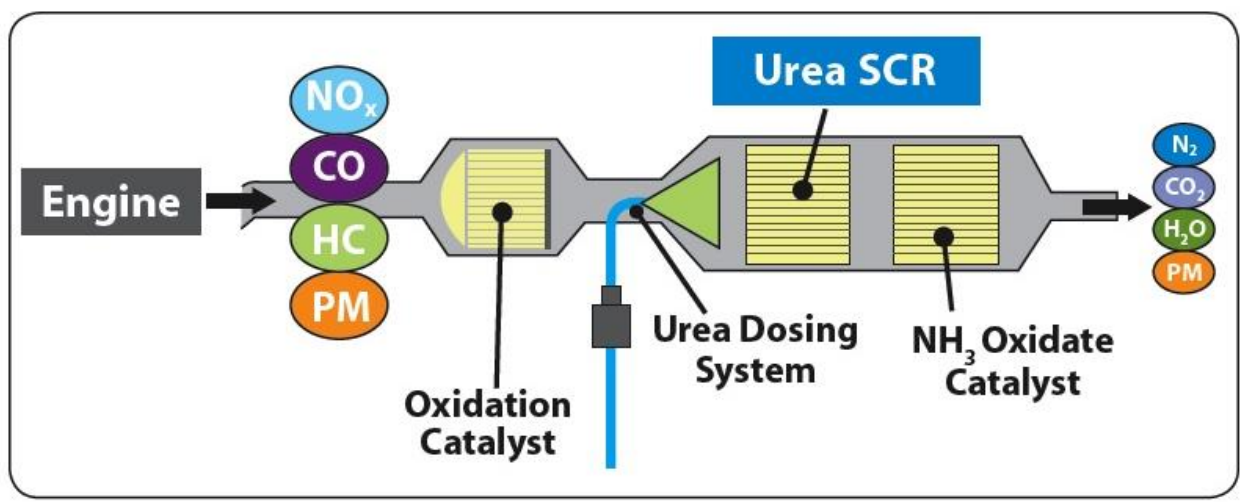

Fig. 2. Diagram of the SCR system. [14]

A particulate filter (Fig. 3) retains soot particles. A filter insert has porous walls, and canals are closed - alternately - on their inlet and outlet. The pore diameter is smaller than that of soot particles, which are then stopped inside the filter and burned. Cleaning a particulate filter is done by burning out [7].

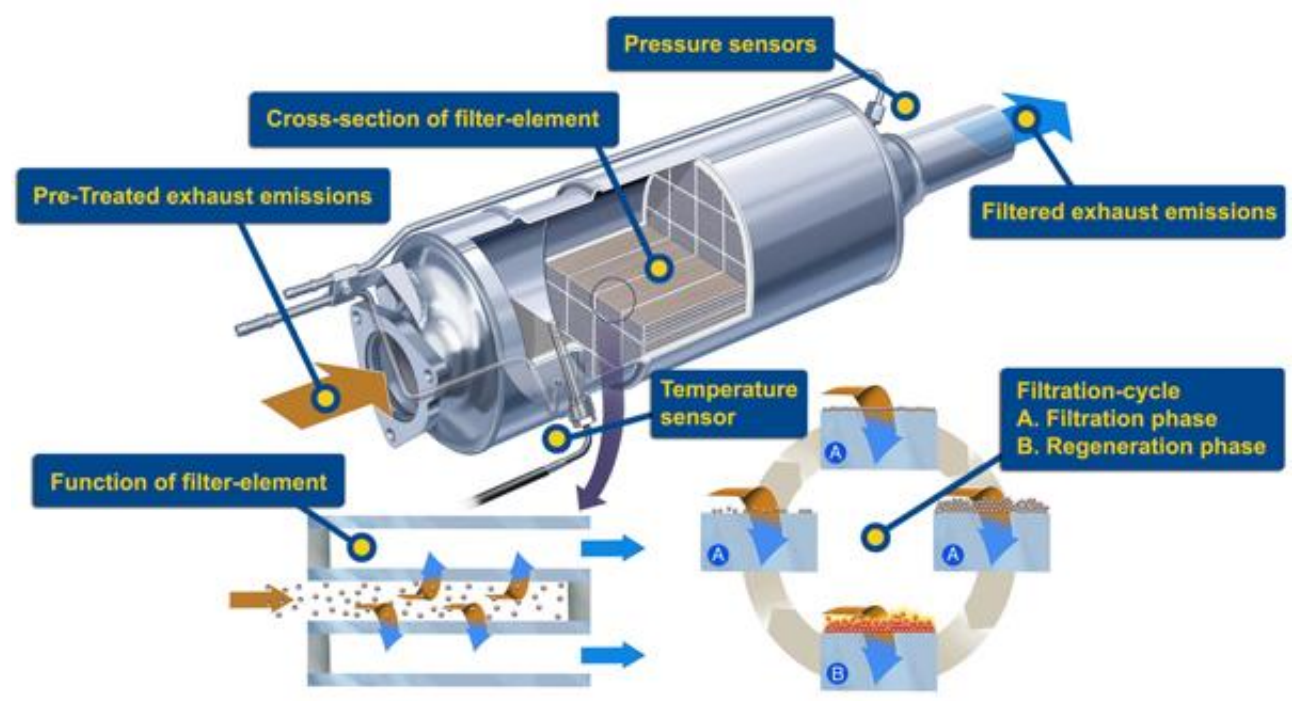

Fig. 3. A diagram of a particulate filter. [11]

Exhaust gas recirculation (EGR) - after-burning - involves reintroducing part of the exhaust gas into the combustion chamber [4]. The EGR system (Fig. 4.) accelerates fuel evaporation, decreases the combustion temperature and oxidises unburned hydrocarbons left in the exhaust gas. The principal aim of the EGR system is a reduction of nitrogen 
oxide $\left(\mathrm{NO}_{\mathrm{x}}\right)$ emission by decreasing the combustion temperature of the oxygen-poor mixture and reducing $\mathrm{HC}$ emission by its oxidation.

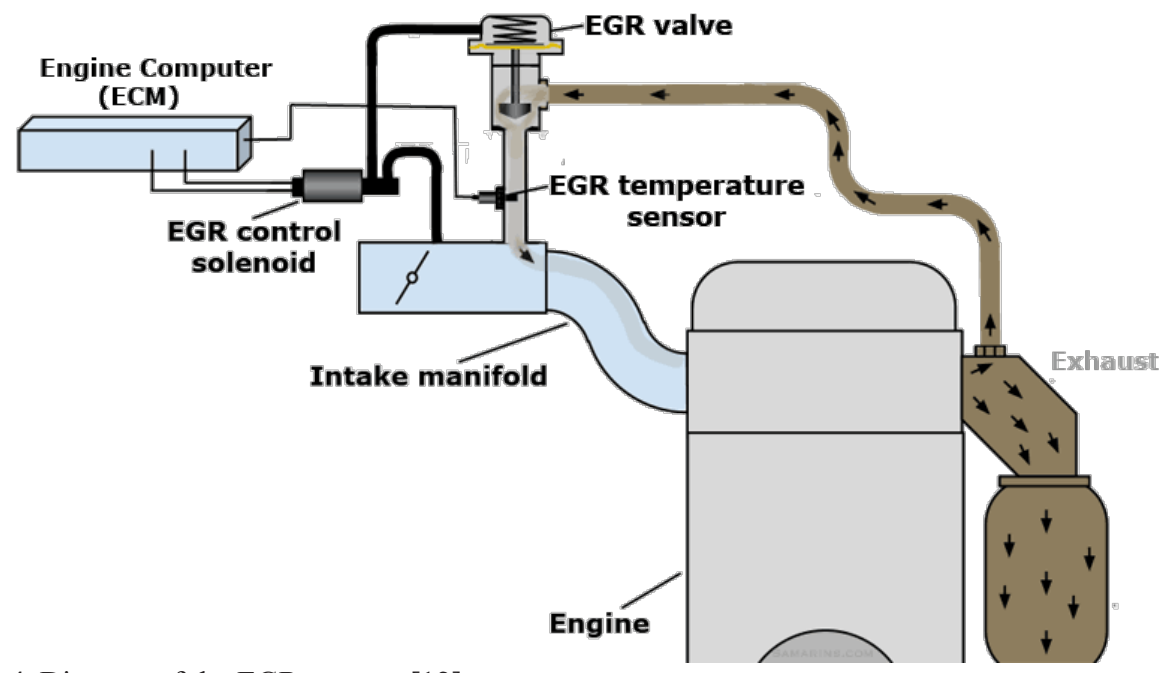

Fig. 4. Diagram of the EGR system. [12]

\section{Study methodology}

Three tractors used in agriculture, with various functional solutions regarding reduction of hazardous emissions, were examined in this study. The tractors were produced in the years 2012-2013. Their nominal towing force was $30 \mathrm{kN}$, and the nominal engine power ranged from 104 to $114 \mathrm{~kW}$. The tractors were of the following types: (Table 1) Case Maxxum 140 Multicontroler, Claas Arion 620 and John Deere 6930.

Tab. 1. Construction parameters of the tractors.

\begin{tabular}{|c|c|c|c|}
\hline Tractor model & $\begin{array}{c}\text { Case Maxxum } 140 \\
\text { Multicontroler }\end{array}$ & Claas Arion 620 & John Deere 6930 \\
\hline Year of manufacture & 2013 & 2012 & 2012 \\
\hline Engine capacity $\left[\mathrm{dm}^{3}\right]$ & 6,7 & 6,7 & 6,7 \\
\hline Number of cylinders & 6 & 6 & 6 \\
\hline Number of valves per cylinder & 4 & 4 & 2 \\
\hline $\begin{array}{l}\text { Nominal engine rotational } \\
\text { speed [rpm] }\end{array}$ & 2200 & 2200 & 2200 \\
\hline Engine power $[\mathrm{kW}]$ & 104 & 114 & 114 \\
\hline Type of gear box & Powershift & Hexashift & Auto PowerQuad \\
\hline $\begin{array}{c}\text { Number of gears } \\
\text { forwards/backwards }\end{array}$ & $16 / 16$ & $24 / 24$ & $20 / 20$ \\
\hline Power take-off speed [rpm] & $\begin{array}{c}540 / 540 \mathrm{ECO} / \\
1000 / 1000 \mathrm{ECO} \\
\end{array}$ & $\begin{array}{c}540 / 540 \mathrm{ECO} / \\
1000 / 1000 \mathrm{ECO} \\
\end{array}$ & $\begin{array}{c}540 / 540 \mathrm{ECO} / \\
1000 / 1000 \mathrm{ECO}\end{array}$ \\
\hline $\begin{array}{l}\text { Hydraulic pump rate of } \\
\text { delivery }[1 / \mathrm{min}]\end{array}$ & 119 & 110 & 138 \\
\hline Length $[\mathrm{mm}]$ & 4532 & 4754 & 4454 \\
\hline
\end{tabular}




\begin{tabular}{|c|c|c|c|} 
Width $[\mathrm{mm}]$ & 2000 & 2000 & 2000 \\
\hline Tyre size front/back & $14.9 \mathrm{R} 28 / 18.4 \mathrm{R} 38$ & $14.9 \mathrm{R} 28 / 20.8 \mathrm{R} 38$ & $14.9 \mathrm{R} 28 / 20.8 \mathrm{R} 38$ \\
\hline
\end{tabular}

The parameters of all the tractors were comparable. They were powered by self-ignition engines and fitted out with a CommonRail fuel injection system. Engines with four valves per cylinder make it possible to achieve a higher air flow and a more rapid response to changes in load. This is a result of the quicker air flow into the combustion chamber and exhaust gas flowing out of it. Moreover, the injector in engines with four valves per cylinder is situated at the centre of a cylinder, which has a beneficial effect on the combustion process.

The Case Maxxum 140 Multicontroler is fitted out with a Powershift gearbox and a SCR (Selective Catalytic Reduction) exhaust gas treatment system and it complies with the exhaust gas Stage IV norm. The Claas Arion 620 has a Hexashift gearbox with 4 groups of gears (A, B, C and D), with 6 half-gears in each. A particulate filter which complied with the Stage IV exhaust gas norm was applied in the tractor as an exhaust gas treatment measure. Unlike the other two, John Deere 6930 had only two valves per cylinder and a variable geometry turbocharger was not applied. The Auto PowerQuad gear had five operation modes, each with four half-gears. The tractor had an EGR system for exhaust gas after-burning.

All of the tractors were tested during the ploughing operation with the same Vogel\&Noot 4-bottom swivel plough. It was fitted out with height and depth regulation capability. The plough weighed $2,230 \mathrm{~kg}$ and it had a working width set at $1.6 \mathrm{~m}$. The plough had divided shares and openwork mouldboards.

The tests were conducted during the autumn ploughing, in a $720 \mathrm{~m}-1$ ong field. After wheat was harvested, it was disked to the depth of $8 \mathrm{~cm}$. The ploughing was done at a depth of $25 \mathrm{~cm}$. The constant ploughing speed of $8 \mathrm{~km} / \mathrm{h}$ at a crankshaft rotational speed of 1,700 rpm ensured the selection of the right gear ratio.

The fuel consumption was measured by the full tank method. The fuel tank in each tractor was filled up at the beginning of work. After an hour's work, the tanks were filled up again with a 11 measuring vessel with a measuring error of $5 \mathrm{ml}$.

The analysis of exhaust gas was carried out with Kane Auto Plus 5-2 - a portable, compact exhaust gas analyser (tab. 2). It is a device analysing the content of five gases: $\mathrm{CO}$, $\mathrm{CO}_{2}, \mathrm{O}_{2}, \mathrm{NO}_{\mathrm{x}}$ and $\mathrm{HC}$. The analyser was connected to a dedicated printer which enabled the results to be printed directly. Measurements could be done 90 seconds after the device was switched on. Kane Auto Plus 5-2 has a Bluetooth module, which enabled the wireless transfer of measurement data to the computer. The Kane Live software was installed on a portable computer, on which the data were archived and visualised. Exhaust gas emission was measured in each tractor during a stop at an idle gear and during work under load.

Tab. 2. Measurement range and measurement resolution of individual components of exhaust gas.

\begin{tabular}{|c|c|c|}
\hline Component & Measurement range & Resolution \\
\hline $\mathrm{CO}$ & $0-10 \%$ & $0,01 \%$ \\
\hline $\mathrm{CO}_{2}$ & $0-16 \%$ & $0,1 \%$ \\
\hline $\mathrm{O}_{2}$ & $0-21 \%$ & $0,01 \%$ \\
\hline $\mathrm{HC}$ & $0-5000 \mathrm{ppm}$ & $1 \mathrm{ppm}$ \\
\hline $\mathrm{NO}_{\mathrm{x}}$ & $0-5000 \mathrm{ppm}$ & $1 \mathrm{ppm}$ \\
\hline
\end{tabular}




\section{Results}

\subsection{Fuel consumption}

The data (Fig. 5) show that the fuel consumption was the lowest in the Claas Arion 620 tractor. It was lower by approx. $15 \%$ than in the other tractors, in which it was at a similar level.

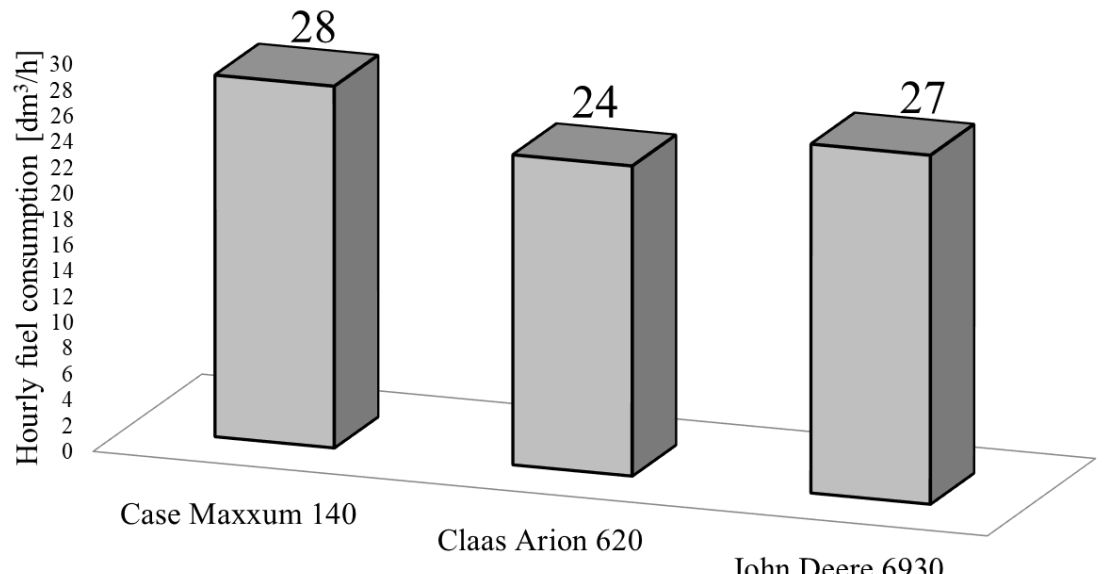

John Deere 6930

Fig 5. Hourlyfuel consumption.

The same relationship was observed when the fuel consumption was divided by the ploughed area. The theoretical productivity was the same for all the tractors: $1.3 \mathrm{ha} / \mathrm{h}$. The fuel consumption was 18.46 1/ha in Claas Arion 620, 20.77 1/ha in John Deere 6930 and 21.54 1/ha in Case Maxxum 140.

The largest fuel consumption was found for the Case Maxxum 140, in which the SCR system with AdBlue liquid was applied. Fuel consumption was also high for the John Deere 6930. This was caused by the lack of a variable-geometry turbocharger and the presence of only two valves per cylinder. Therefore, the engine characteristics and the maximum torque were different, available within a more narrow range of the rotational speed.

\subsection{Exhaust gas emission}

Measurements of exhaust gas emission included determination of $\mathrm{CO}_{2}, \mathrm{CO}, \mathrm{O}_{2}$ and $\mathrm{NO}_{\mathrm{x}}$ contents (Fig. $6-9$ ).

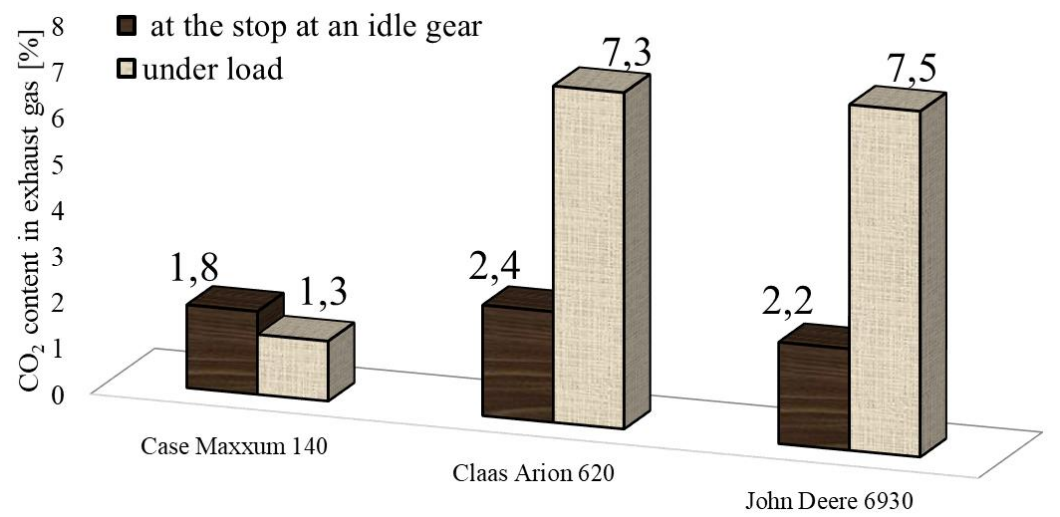

Fig. 6. $\mathrm{CO}_{2}$ content in exhaust gas. 
The SCR system with AdBlue liquid in the Case Maxxum 140 tractor proved to be the best option (Fig. 6) for $\mathrm{CO}_{2}$ reduction in exhaust gas. The content of $\mathrm{CO}_{2}$ was lower (by as much as six times) compared to other tractors - both at the stop at an idle gear and under load. Particularly large differences in exhaust gas emission were visible under load. The $\mathrm{CO}_{2}$ content in Case Maxxum 140 was several times lower compared to the other two tractors. The content of $\mathrm{CO}_{2}$ in exhaust gas from Claas Arion 620 and John Deere 6930 was similar.

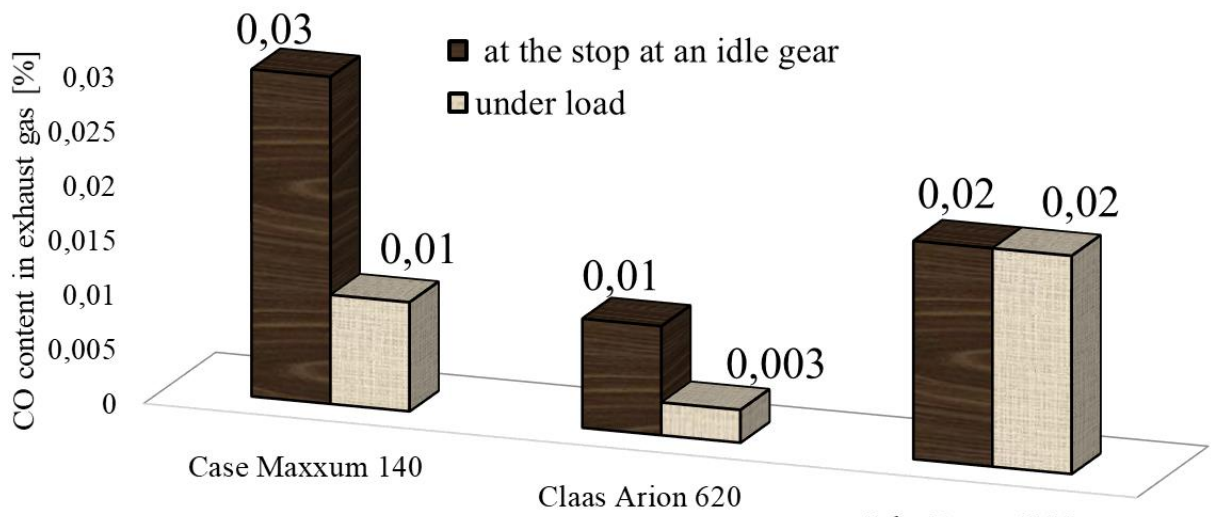

John Deere 6930

Fig. 7. CO content in exhaust gas.

Data presented in Fig. 7 show that exhaust gas from the Claas Arion 620 tractor contained the lowest amounts of CO. In this case, much lower amounts of CO were found both during the stop, at an idle gear, and under load. This was a consequence of applying a particulate filter; moreover, the engine had four valves per cylinder. Owing to the latter, the fuel combustion process could be optimised. Moreover, installation of a varied-geometry turbocharger allowed for the maximum torque within a broader range of rotational speeds. A particularly high content of CO in exhaust gas from Case Maxxum 140 was observed during the engine work at a stop at the idle gear. The CO content was associated with the fuel consumption. A tractor which consumes less fuel emits less CO.

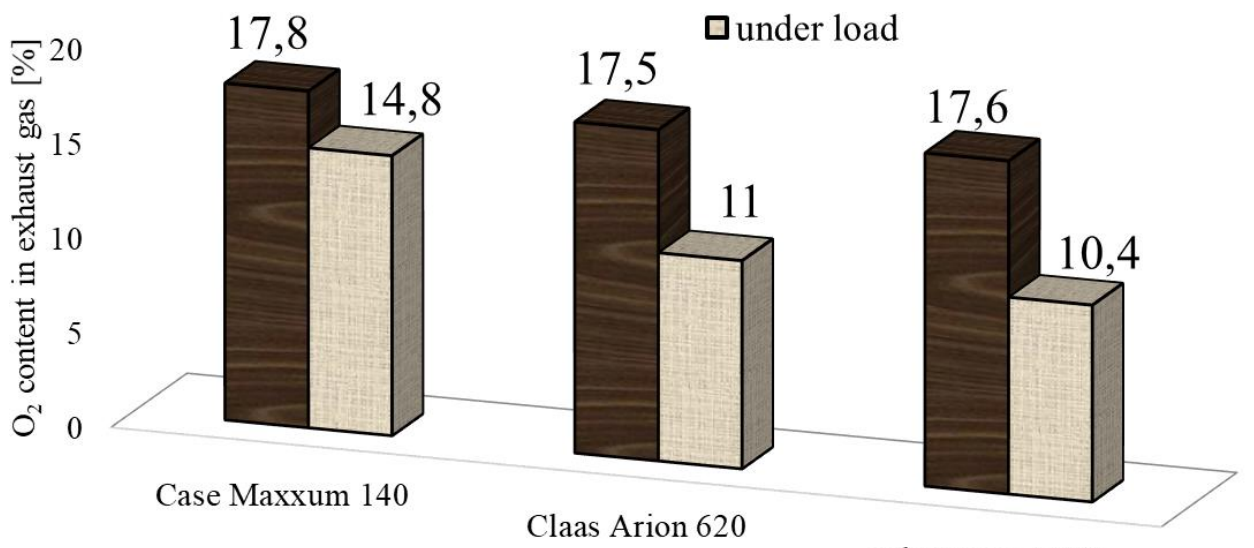

John Deere 6930

Fig. 8. $\mathrm{O}_{2}$ content in exhaust gas.

The data presented in Fig. 8 show that the content of $\mathrm{O}_{2}$ in exhaust gas was similar during a stop at an idle gear. On the other hand, the lowest amounts of $\mathrm{O}_{2}$ during work under load were found in exhaust gas from Claas Arion 620. Oxygen initiates reactions that take place during combustion. It is also used in exhaust gas treatment systems for oxidation 
of the $\mathrm{CO}$ and $\mathrm{HC}$ in exhaust gas. The smaller the amount of $\mathrm{O}_{2}$ in exhaust gas, the more efficient the combustion and oxidation process.

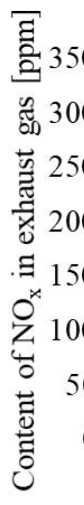

$\square$ at the stop at an idle gear

空 300

范 250

$\Xi 150$

$\begin{array}{rr}0^{x} & 150 \\ 0^{4} & 100 \\ 0 & \\ 0 & 50 \\ 0 & 0 \\ 0 & 0\end{array}$

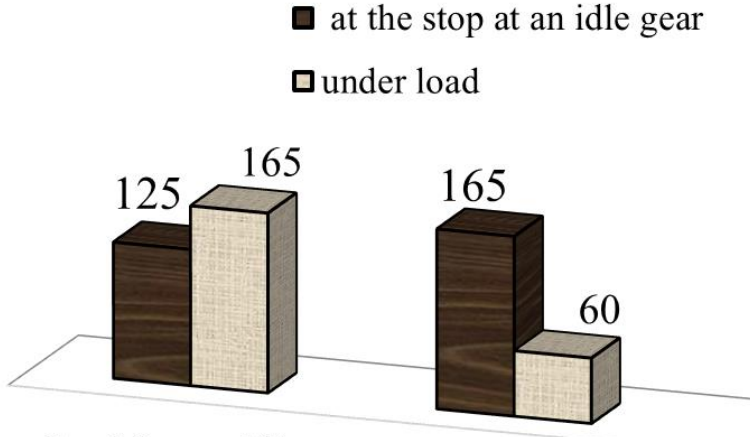

Case Maxxum 140

Claas Arion 620

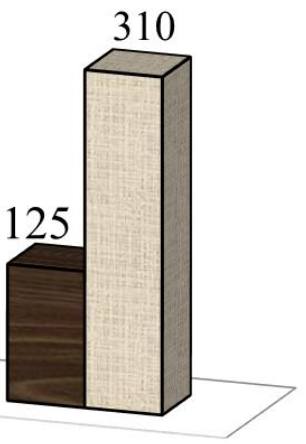

John Deere 6930

Fig. 9. Content of $\mathrm{NO}_{\mathrm{x}}$ in exhaust gas.

Fig. 9 shows the content of $\mathrm{NO}_{\mathrm{x}}$ in exhaust gas. It reveals a much higher content of these substances in exhaust gas from the John Deere 6930 tractor. This was a consequence of the fact that the engine did not have a particulate filter or an SCR system with AdBlue liquid. The most effective reduction of $\mathrm{NO}_{\mathrm{x}}$ was achieved in the Claas Arion 620 tractor, which was fitted out with a particulate filter.

\section{Conclusion}

The results of these experiments have shown that functional solutions in agricultural tractors have a great effect on fuel consumption and exhaust gas emission. The tractors complied with the same emission norms and did the same work, although the differences in exhaust gas emission between them were considerable.

The Claas Arion 620 tractor had the lowest fuel consumption. Savings of $15 \%$ contribute to the economic benefits in agricultural activities. Fuel consumption by the Case Maxxum 140 Multicontroler and John Deere 6930 was similar.

An analysis of all the components of exhaust gas shows that the reduction of hazardous substances content was the least effective in the John Deere 6930 tractor. The exhaust gas treatment system was the least complex, with no particulate filter or the SCR system with AdBlue liquid, and the engine supply system was the least advanced. The exhaust gas in the Case Maxxum 140 tractor, which was fitted out with an SCR system with AdBlue liquid, was found to contain several times less $\mathrm{CO}_{2}$ compared to the other two tractors. Exhaust gas from Claas Arion 620, which was fitted out with a particulate filter, contained the smallest amounts of $\mathrm{CO}$ and $\mathrm{NO}_{\mathrm{x}}$.

This experiment has not given a conclusive answer about the system with the best capability for reduction of hazardous substance content. This is because a particulate filter is more effective in reducing the content of $\mathrm{CO}$ and $\mathrm{NO}_{\mathrm{x}}$, whereas the SCR system with AdBlue liquid is better at reducing the content of $\mathrm{CO}_{2}$.

\section{Bibliography}

1. K. Baumgard, S. Cooke, John Deere Power Systems Symposium (2005)

2. A. Bieniek, Agricultural Engineering, 143, 31 (2013)

3. G. Chomik, Z. Chomik, Nowoczesna Obstuga Techniczna Ciagników (2016)

4. J. Gromadko, V. Hong, P. Miler, Maintenance and Rel. 4, 63 (2008) 
5. S. Jung, M. Ishida, S. Yamamoto, H. Ueki, D. Sakaguchi, International J. of Autom. T. 11, $611(2010)$

6. A. Karbowy, A. Koniuszy, P. Sędłak, Teka Com. Mot. Ener. in Agric. 12, 69 (2012)

7. A. Mazanek, J. Jakóbiec, W. Piekarski, Logistyka 5, 381 (2015)

8. J. Merkisz, P. Lijewski, P. Fuć, S. Weymann, Maintenance and Rel. 15, 364 (2013)

9. J. Merkisz, J. Pielecha, S. Radzimirski, Emisja Zanieczyszczeń Motoryz. (2012)

10. A. A. Naji, A Comparison of Measured Diesel Emis. in Agr. (2013)

11. J. Skudlarski, Roczniki naukowe Stow. Ekon. Rol. i Agrob. 19, 65 (2017)

12. www.maasradiator.com/dpf-services

13. www.samarins.com/diagnose/diagrams

14.www.silniki.info.pl/ochrona_srodowiska.html

15. www.tomorrowstechnician.com/how-long-should-a-brake-job-last 